\title{
THREE DIMENSIONAL IMAGE ANALYSIS OF MINOR SALIVARY GLANDS IN 180-DAY RATS BORN WITH MACROSOMIA
}

\author{
Olga Garmash'1, Galina Gubina-Vakulik², Vondrášek David³. \\ ${ }^{1}$ Kharkiv National Medical University, Therapeutic Dentistry Department, Kharkiv, Ukraine \\ ${ }^{2}$ Kharkiv National Medical University, Pathological Anatomy Department, Kharkiv, Ukraine \\ ${ }^{3}$ Institute of Physiology of the Czech Academy of Sciences, Department of Biomathematics, Prague, Czech Republic
}

\section{ANALIZA 3D SLIKE MINORNIH PLJUVAČNIH ŽLEZDA KOD PACOVA ROĐENIH SA MAKROZOMIJOM I STARIH 180 DANA}

\author{
Olga Garmašl, Galina Gubina-Vakulik², Vondrašek David³. \\ ${ }^{1}$ Harkov Nacionalni Medicinski Univerzitet, Katedra za terapeutsku stomatologiju, Harkov, Ukrajina \\ ${ }^{2}$ Harkov Nacionalni Medicinski Univerzitet, Katedra za patološku anatomiju, Harkov, Ukrajina \\ ${ }^{3}$ Akademija nauka Češke, Institut za fiziologiju, Katedra za biomatematiku, Prag, Češka
}

\begin{abstract}
Objective. To determine the morphometric differences in the minor buccal salivary glands in rats aged 6 months with fetal macrosomia (groups under study) and in rats aged 6 months after a normal intrauterine development (control group) by using a 3-D analysis technique.

Methods. The fetal macrosomia was induced in four different ways. To apply the morphological analysis, the tissues of oral cavity mucosa of six-month-old rats were used. The 3-D images acquired by confocal microscopy were used for estimating the morphometrical characteristics of minor buccal salivary gland microscopic structures.

Results. On reaching the age of six months, the descendants of the rats in all macrosomic groups have the average body weight, the average body length, and the average weight-to-length ratio comparable to those in the Control Group.

In rats born with different fetal macrosomia modeling, when the age of 6 months was reached, the deviations in the Groups under study from the Control Group were found to appear to various degree in the following parameters: the acinus area, the acinus gap area, the number of mucous acinar cells in the acinus, the height of the cytoplasm of mucous acinar cells, and the percentage fractions of the relative area of mucous acinar cells cross-sections, area of acinar gap cross-sections and relative area of glandular stroma.

Conclusion. The clustered technique assessment of these deviations brings us to the conclusion about the presence of hypoplasia of minor buccal salivary glands in rats born with fetal macrosomia.
\end{abstract}

Keywords: fetal macrosomia; rats; salivary glands, minor; microscopy, confocal.

\section{INTRODUCTION}

In recent decades, there has been a tendency to increase average body mass index values in newborn children in many countries all over the world [1]. Macrosomia is determined when the weight of the newborn child is equal to or greater than 4,000 $\mathrm{g}$ [2].

\section{SAŽETAK}

Cilj. Odrediti morfometrijske razlike minornih bukalnih pljuvačnih žlezda kod pacova starih 6 meseci sa fetalnom makrozomijom (ispitivana grupa) $i$ kod pacova starih 6 meseci nakon normalnog intrauterinog razvoja (kontrolna grupa), korišćenjem tehnike 3-D analize.

Metodologija. Fetalna makrozomija je indukovana na 4 različita načina. Kako bi se sprovela morfološka analiza, korišćena su tkiva sluznice usne duplje kod šestomesečnih pacova. Procena morfometrijskih karakteristika mikroskopskih struktura minornih bukalnih pljuvačnih žlezda je vršena korišćenjem 3-D slika dobijenih konfokalnom mikroskopijom.

Rezultati. Nakon dostizanja starosti od 6 meseci, potomci pacova svih makrozomijskih grupa su imali prosečnu telesnu težinu, dužinu $i$ odnos težina-dužina u poređenju sa kontrolnom grupom. Kod pacova rođenih sa različitim modelima fetalne makrozomije, nakon postizanja starosti od 6 meseci, devijacije u ispitivanim grupama u odnosu na kontrolnu grupu su pronađene u različitim stepenima sledećih parametara: površina acinusa, površina acinusne šupljine, broj mukoznih acinusnih ćelija u acinusu, visina citoplazme u mukoznim acinusnim ćelijama, procenat frakcije relativne površine poprečnog preseka mukoznih acinusnih ćelija, površina poprečnog preseka acinusne šupljine i relativna površina žlezdane strome.

Zaključak. Procena klaster tehnike ovih devijacija dovela nas je do zaključka o postajanju hipoplazije kod minornih bukalnih pljuvačnih žlezda kod pacova rođenih sa fetalnom makrozomijom.

Ključne reči: fetalna makrozomija; pacovi; pljuvačne žlezde, minorne; mikroskopija, konfokalna.

Numerous data given in a number of works witness that the development of dental violations have strong connection with the state of person's health and with the presence of various diseases including those caused by metabolic mechanisms $[3,4,5,6,7,8]$. However, relatively few studies have been performed to examine the effect of fetal macrosomia on dental pathology formation. In such 
studies, researchers have pointed only to the issue of caries occurrence in children and adolescents $[9,10]$. The effect of fetal macrosomia on other organs, such as salivary glands, has been studied very sparsely up to now.

The three pairs of major salivary glands, glandula parotidea, glandula submandibularis, and glandula sublingualis, have been studied in detail for centuries. The classification of minor salivary glands is based on topographic features. These glands are classified into glandulae molares, glandulae buccales, glandulae labiales, glandulae linguales, and glandulae palatinae.

Salivary glands consist of stroma and parenchyma. Stroma is a connective tissue membrane with interlobular septi, which cover ducti and blood vessels. Parenchyma consists of acini and excretory ducti. Aciniare is formed of secretory cells and of mioepythelial cells, whose contraction over the periphery of acini results in the release of saliva. All salivary glands, depending on the type of their secret, are divided into albuminous or serous glands, mucous glands and glands producing a mixed serous and mucous secretion. Serous glands produce a fluid protein-rich secret. This type of salivary gland includes parotid glands and gustatory (Ebner's) glands. Mucous glands (palatine) produce a thick glycoproteinrich secret. The third type of gland is represented by submandibular and sublingual glands, buccal, labial and tongue glands; these glands produce proteins and mucous secret. Acini of the third type of gland are high in mucous cells acinar content and low in serous acinar cell content.

The minor salivary glands are located throughout the oral cavity: individually in small groups within the submucosa of the oral mucosa in the mucous tissue or between muscle fibers of the tongue.

The anatomical and functional state of salivary glands and the amount and quality of saliva which they produce have a noticeable effect on dental health $[11,12]$.

Numerous publications reported a significant influence of malfunctioning of the major salivary glands on health condition of oral cavity organs $[13,14]$.

Yet, the minor salivary glands have been studied insufficiently due to their small size. There are very few publications about the state of the minor salivary glands developed under conditions of perinatal pathology including fetal macrosomia $[15,16]$.

Detection of morphological changes in the minor salivary glands can determine elements of pathogenesis of the formation of dental disorders in children who were born with fetal macrosomia. This can help with development of prevention and correction of abnormal conditions of hard tooth tissues in the preclinical phase of the pathological process.

Confocal microscopy enables to acquire 3D images of internal structure and their subsequent morphometric analysis $[17,18,19,20]$.The 3D analysis of microscopic structures can facilitate the analysis of the relationship between structure and function in the minor anterior and posterior buccal salivary glands.

As shown above, there is an urgent need for examination of the minor anterior and posterior buccal salivary glands in experimental animals born with macrosomia. This includes morphological studies, which can establish dominating links between the examination results and dental pathology.

The aim of our investigation was to determine morphometric differences in the minor buccal salivary glands in rats with fetal macrosomia (groups under study) and in rats after normal intrauterine development (control group).

\section{MATERIAL AND METHODS}

Subjects. The experiment on macrosomia formation was conducted to examine morphological features of the minor salivary glands in rats born with macrosomia. The Wistar Albino Glaxo rats aged 180 days were used in all experiments. Caring and using the experimental animals meet the requirements of the national «General ethical principles of Ethical Conduct in the Care and Use of Animals» (Ukraine, 2001), which are in agreement with the provisions of "European Convention for the Protection of Vertebrate Animals used for Experimental and other Scientific Purposes" (Strasbourg, 1986).

Experimental procedures. The preferred models for the study of macrosomia were hypernutrition and diabetes induction. The animals were divided in five groups of $5-$ 6 animals in each, which is commonly acceptable in pathomorphological investigations. Four different models were used for macrosomia formation in four separate groups (the fifth group was a control one):

(1) Physical Development Acceleration Group consists of the oversized ( $\mathrm{m} \geq 6.3 \times 10^{-3} \mathrm{~kg}$ ) descendants of young ( $3-5$ months) animals with average weight-height parameters and standard nutrition ration before zoogamy and during pregnancy [21].

(2) Young+Diet Group consists of the oversized descendants of young ( $3-5$ months) animals with average weight-height parameters and high-calorie diet before zoogamy and during pregnancy (Gubina-Vakulik GI 1994) [22].

(3) Mature+Diet Group consist of oversized descendants of middle aged ( $8-9$ months) animals with average weight-height parameters and the standard nutrition ration before zoogamy and during pregnancy (Gubina-Vakulik GI 1994) [22].

(4) Hypokinetic+Diet Group consists of the oversized descendants of young ( $3-5$ months) animals 
with average weight-height parameters and high-calorie, diet before zoogamy and during pregnancy and were kept in mild hypokinetic conditions.

(5) Control Group consists of animals with the average weight-height parameters whose mothers have the standard nutrition ratio and their pregnancy passed under common conditions. Descendants from different litters are used to form each of the groups.

All descendant rats were fed standard balanced nutrition, had free access to tap water, and were held under the principles of Good Laboratory Practice.

To diagnose macrosomia standard clinical criterion (body weight in excess of the 90-percentile level) within a large number (500) of newborn rats was used. All groups had roughly comparable ratio of male and female species. The somatometric examination of the rats (weighing, measurement of body length, and tail length) is conducted twice: at birth and immediately before withdrawing animals from the experiment (Table 1).

In Table 1, the Initial examination refers to the data acquired for the one-day-old rats, and repeated examination refers to the data acquired for the same rats aged 180 days.

As the material for the study, we have used tissues of oral mucosa taken from the area of projection of upper and lower jaw molars, namely the minor buccal salivary glands (see Figure 3).

Table 1. Results on Morphometric Studies of Experimental Animals
Confocal microscopy. All results of the confocal laser scanning microscopy were acquired using the Leica SP8 AOBS laser scanning confocal microscope (LSCM) at the inverted Leica DMi8 microscope stand installed at the Department of Biomathematics, Institute of Physiology, Czech Academy of Sciences (Prague, Czech Republic).

To confirm and visualize hemodynamic and structural changes in minor buccal salivary glands in the species under study, serial slides, 20-70 $\mu \mathrm{m}$ thick, stained by hematoxylin and eosin (H\&E) were made.

In the single-photon excitation mode, an Argon (488 $\mathrm{nm}$ ) laser, which is part of the microscope equipment, was used. Laser power setting was measured at 100\% intensity setting with laser power set to $100 \%$ and to $9.52 \%$ respectively. Laser power at sample focal plane of ACS APON 40x1.15 Oil CS lens was $1.14 \mathrm{~mW}$ for $100 \%$ laser power and $0.27 \mathrm{~mW}$ for $9.52 \%$ laser power. Leica power setting during sample acquisition was set to $9.52 \%$ to avoid photobleaching of the sample, while intensity setting was set to $2.5 \%$ for all samples to avoid saturation of an image.

We optimized setting of excitation and detection wavelengths for H\&E imaging as follows. First, using excitation wavelength of $488 \mathrm{~nm}$, the detection range was optimized using Lambda scan mode. Emission spectra peaks were detected at wavelengths ranging from $500 \mathrm{~nm}$ to $600 \mathrm{~nm}$ (Figure 1). Further, we checked additional emission peaks using tunable pulse scanning multi-photon

\begin{tabular}{|c|c|c|c|}
\hline Groups under Study & $\begin{array}{l}\text { Average body weight } \\
\qquad\left(\mathrm{kg} \times 10^{3}\right)\end{array}$ & $\begin{array}{l}\text { Average bodylength } \\
\qquad\left(\mathrm{m} \times 10^{2}\right)\end{array}$ & $\begin{array}{c}\text { Average weight-to-length } \\
\text { ratio }\left(\mathrm{g} / \mathrm{cm}^{2}\right)\end{array}$ \\
\hline \multicolumn{4}{|c|}{ Initial examination } \\
\hline Control & 5.633 & 5.017 & 0.225 \\
\hline Young+Diet & $\begin{array}{c}6.667 * \\
p=0.004\end{array}$ & 5.000 & $\begin{array}{c}0.268^{*} \\
p=0.010\end{array}$ \\
\hline Mature+Diet & $\begin{array}{c}7.183 * \\
p=0.004\end{array}$ & $\begin{array}{c}5.667^{*} \\
p=0.012\end{array}$ & 0.224 \\
\hline $\begin{array}{c}\text { Physical Development } \\
\text { Acceleration }\end{array}$ & $\begin{array}{c}7.05^{*} \\
p=0.004\end{array}$ & $\begin{array}{c}6.117^{*} \\
p=0.004\end{array}$ & $\begin{array}{c}0.188^{*} \\
p=0.007\end{array}$ \\
\hline Hypokinetic+Diet & $\begin{array}{c}7.04^{*} \\
p=0.006\end{array}$ & 5.140 & $\begin{array}{c}0.266^{*} \\
p=0.006\end{array}$ \\
\hline \multicolumn{4}{|c|}{ Repeated examination } \\
\hline Control $_{180}$ & 188.333 & 17.520 & 0.595 \\
\hline Young+Diet 180 & 192.500 & 17.833 & 0.596 \\
\hline Mature+Diet $_{180}$ & 198.333 & 17.750 & 0.618 \\
\hline $\begin{array}{c}\text { Physical Development } \\
\text { Acceleration }_{180}\end{array}$ & 220.000 & 18.750 & 0.625 \\
\hline Hypokinetic+Diet $_{180}$ & 157.600 & 17.323 & 0.526 \\
\hline
\end{tabular}

* - The difference between the groups of large-weight rats and middleweight rats (control) is significant (within the 0.95 confidence interval). 
Table 2. Results on Morphometric Studies of Minor Salivary Glands in Test Animals

\begin{tabular}{|c|c|c|c|}
\hline Groups under Study & $\begin{array}{c}\text { Relative area of acini } \\
\text { cross-sections (\%) }\end{array}$ & $\begin{array}{c}\text { Relative area of acinar } \\
\text { gap cross-sections (\%) }\end{array}$ & $\begin{array}{c}\text { Relative surface area of } \\
\text { glandular stroma (\%) }\end{array}$ \\
\hline Control $_{180}$ & 59.3 & 1.8 & 38.9 \\
\hline Young+diet $_{180}$ & 55.9 & 1.6 & 42.5 \\
\hline Mature+diet & & $9.0^{*}$ \\
$p=0.027$ & 35.0 \\
\hline $\begin{array}{c}\text { Physical Development } \\
\text { Acceleration }\end{array} 180$ & 56.0 & $3.9^{*}$ & 42.0 \\
\hline Hypokinetic+diet & & $5=0.037$ & 37.5 \\
\hline
\end{tabular}

* - The difference between the groups of large-weight rats and middleweight rats (control) is significant (within the 0.95 confidence interval).

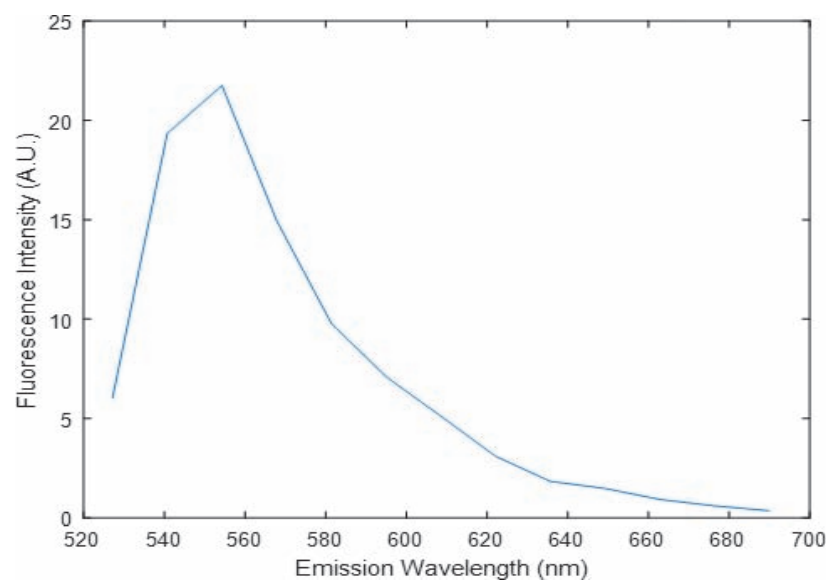

Figure 1. Detection spectrum for the excitation wavelength of $488 \mathrm{~nm}$. Dependence of the fluorescence intensity versus wavelength at the single-photon excitation sections of tissue preparations experimental animals stained by hematoxylin and eosin. Emission spectra acquired by spectral scanning, implemented in standard Leica Confocal SoftwareAdvanced Fluorescence ( $L A S A F$ ) for confocal microscope

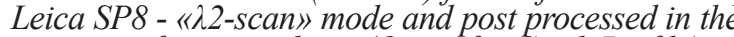
same software package (Quantify - Stack Profile).

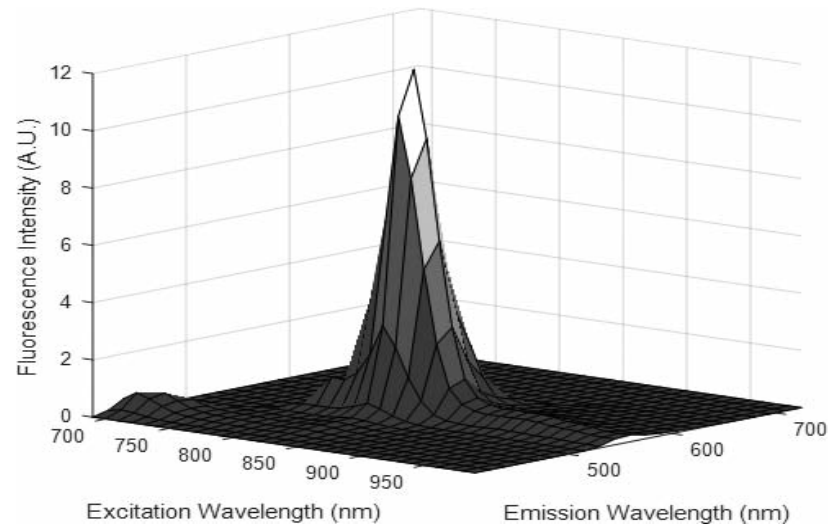

Figure 2. Emission characteristics of hematoxylin and eosin stained specimen excited by multiphoton laser.

Multiphoton laser was pulsing from $690 \mathrm{~nm}$ to $990 \mathrm{~nm}$

with the interval of $10 \mathrm{~nm}$. Bandpass wavelength was selected on the HyD detectors for each wavelength in the detection window of $15 \mathrm{~nm}$.

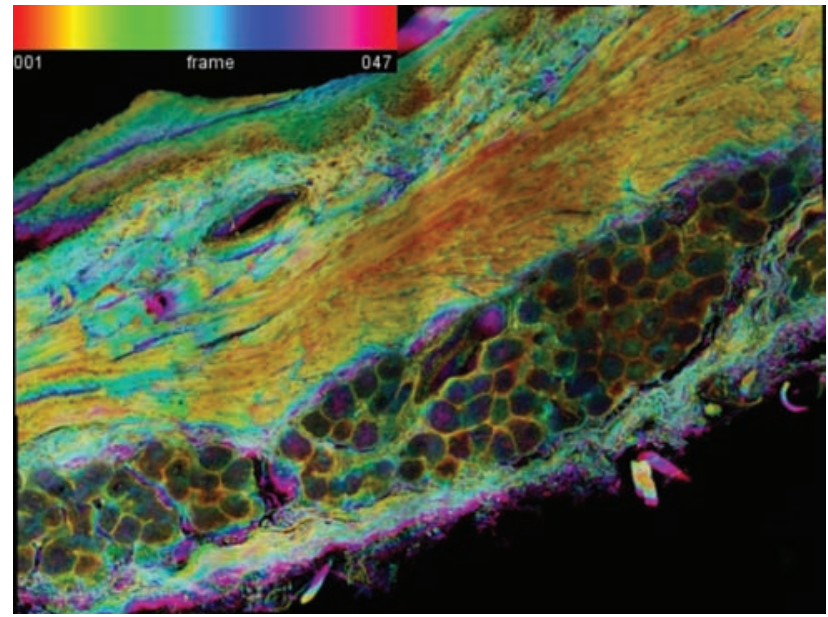

Figure 3. Fragment of buccal minor salivary gland, 180day rat Control Group, depth color coding of Maximum projection of color-coded z-stack (stack of confocal micrographs) (47 optical sections). The physical size of the

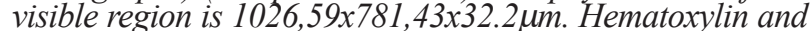

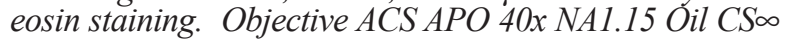
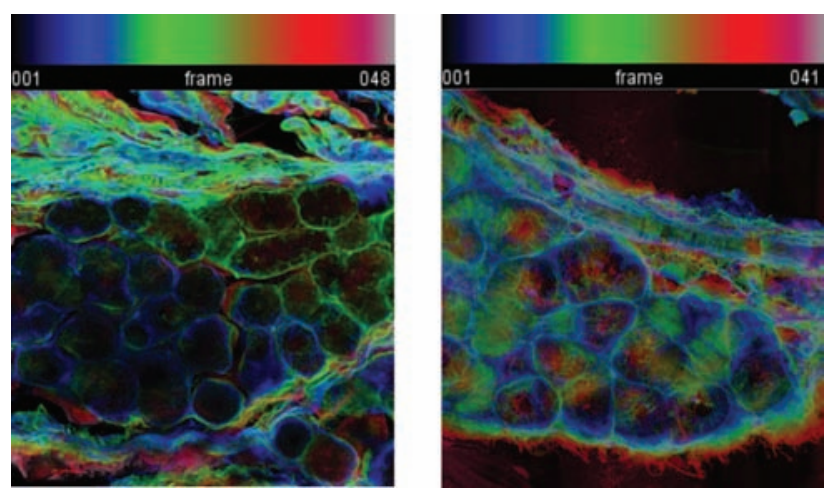

Figure 4. Fragments of buccal minor salivary gland, 180day rats. Left pannel: Young+diet Group, depth color coding of Maximum projection of color-coded z-stack (48 optical sections), the physical size of the visible regionis 276,79x276,79x32,9 um. Right pannel: Mature+diet Group, depth color coding of Maximum projection of color-coded $z$-stack (41 optical sections), the physical size of the visible regionis 276,79x276,79x28um. Hematoxylin and eosin

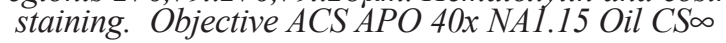


Table 3. Results on Morphometric Studies of Minor Salivary Glands in Test Animals

\begin{tabular}{|c|c|c|c|c|c|c|}
\hline $\begin{array}{l}\text { Groups under } \\
\text { Study }\end{array}$ & $\begin{array}{l}\text { Average area } \\
\text { of minor } \\
\text { salivary } \\
\text { gland acini } \\
\text { cross- } \\
\text { sections } \\
(\mu \mathrm{m})^{2}\end{array}$ & $\begin{array}{l}\text { Average } \\
\text { area of } \\
\text { minor } \\
\text { salivary } \\
\text { gland acini } \\
\text { Gap cross- } \\
\text { sections } \\
(\mu \mathrm{m})^{2}\end{array}$ & $\begin{array}{l}\text { Average area } \\
\text { of mucous } \\
\text { acinar cells in } \\
\text { minor } \\
\text { salivary gland } \\
\text { acini cross- } \\
\text { sections } \\
(\mu \mathrm{m})^{2}\end{array}$ & $\begin{array}{l}\text { Average } \\
\text { perimeter of } \\
\text { minor } \\
\text { salivary } \\
\text { gland acini } \\
(\mu \mathrm{m})\end{array}$ & $\begin{array}{l}\text { Average } \\
\text { number of } \\
\text { mucous } \\
\text { acinar cells } \\
\text { of acini } \\
\text { cross- } \\
\text { section }\end{array}$ & $\begin{array}{c}\text { Cytoplasm } \\
\text { height } \\
(\mu \mathrm{m})\end{array}$ \\
\hline Control $_{180}$ & 2028.1 & 61.4 & 1966.8 & 175.8 & 11.5 & 22.0 \\
\hline Young+diet 180 & $\begin{array}{l}1341.3^{*} \\
p=0.028\end{array}$ & 44.7 & $\begin{array}{l}1296.6^{*} \\
p=0.014\end{array}$ & $\begin{array}{c}142.6^{*} \\
p=0.028\end{array}$ & 11.1 & 18.2 \\
\hline Mature $+\operatorname{diet}_{180}$ & 1833.0 & 254.6 & 1578.5 & 167.1 & 11.5 & $\begin{array}{c}15.9^{*} \\
p=0.037\end{array}$ \\
\hline $\begin{array}{c}\text { Physical } \\
\text { Development } \\
\text { Acceleration }_{180}\end{array}$ & 1764.3 & 108.5 & 1655.9 & 159.1 & 9.8 & 17.5 \\
\hline $\begin{array}{l}\text { Hypokinetic } \\
\quad+\text { diet }_{180}\end{array}$ & 1534.9 & $\begin{array}{c}12.6^{*} \\
p=0.014\end{array}$ & 1522.2 & 149.9 & $\begin{array}{c}10.1^{*} \\
p=0.050\end{array}$ & 20.5 \\
\hline
\end{tabular}

* - The difference between the groups of large-weight rats and middleweight rats (control) is significant (within the 0.95 confidence interval).

Ti:Sapphire laser Chameleon Ultra. Various excitation wavelengths were applied using the detection window of $15 \mathrm{~nm}$. Single emission peak was detected (Figure 2). Therefore, we used single excitation wavelength of 488 $\mathrm{nm}$ and detection range of $500-600 \mathrm{~nm}$ to obtain optimal signal from H\&E stained tissue sections.

The acini have a complex shape and are located at different depth in the sample. The three-dimensional image obtained as a result of confocal scanning of the salivary gland samples allowed us to determine the size of each acinus in any its part and thus to obtain its exact whole sizes and to study acinus anatomical features. To determine the mean acini parameters in the sample of the
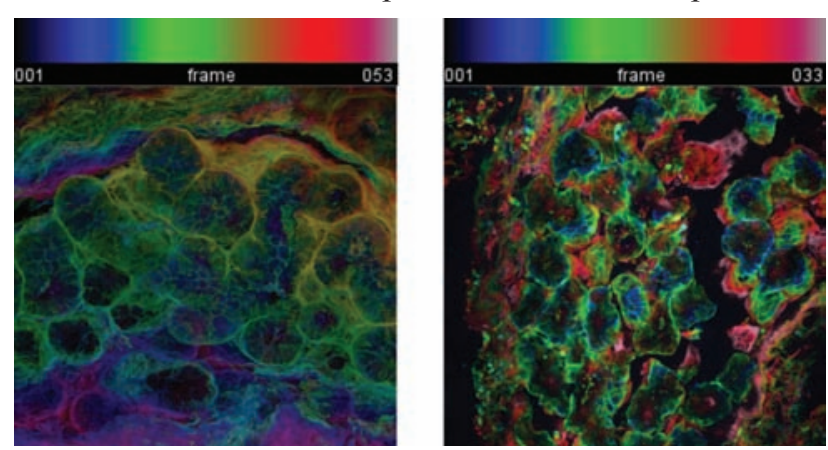

Figure 5. Fragments of buccal minor salivary gland, 180day rats. Left pannel: Physical Development Acceleration Group, depth color coding of Maximum projection of color-coded z-stack (53 optical sections), the physical size

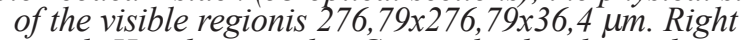
pannel: Hypokinetic +diet Group, depth color coding of

Maximum projection of color-coded $z$-stack (33 optical sections), the physical size of the visible regionis

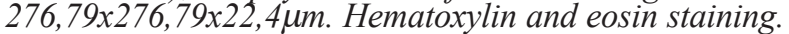

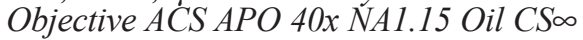

salivary gland, the layer in the microphotograph stack was chosen where the acinus cross section attains a maximum. Since the acini are located at different depths in the sample, their specific values must be determined from different microphotographs, which is possible by using confocal microscopy.

The animals in each group were kept under the same housing conditions. The minor salivary glands in animals within one group were subjected to similar exogenous and endogenous factors and produced a saliva of similar quality. The samples of the minor salivary glands were taken from the same topographic areas. In each animal in each group, one minor salivary gland was analyzed when the gland sample contained $40-120$ acini. Under the experimental conditions described above, the number of statistically independent samples cannot be increased.

Mophometric parameters of minor salivary glands. The following parameters were measured in each sample: the surface area of every minor salivary gland acinus in its the widest part, the surface area of every minor salivary gland acinus gap, the surface area of every mucous acinar cell in minor salivary glands, and the perimeter of every acinus in its widest part. These measurements were made with the Fiji plugin tool called Measure [23].

Statistical analysis. The mean of each parameter and the cytoplasm height were calculated with Exel, The number of acinar cells was counted in that microphograph where the acini have a maximum cross section.

The percentage fractions of the relative area of mucous acinar cells cross-sections, area of acinar gap crosssections and relative area of glandular stroma was determined using the Avtandilov grid. 
Subsequently, the means for the each Macrosomic Group and Control Group pair were compared with the Mann-Whitney $U$ test run at the $\mathrm{p} \leq 0.05$ level of significance with the Statistica 6.0. Each Group was comprised of 5-6 independent samples.

\section{RESULTS}

Using average weight-to-length ratio $\left(\mathrm{g} / \mathrm{cm}^{2}\right)$, we detected the signs of the intrauterine obesity in the macrosomic rats in the Young+Diet and Hypokinetic+Diet groups and the signs of the body weight deficiency with regard to their relatively long length in the macrosomic rats in the Physical Development Acceleration Group (see Table 1).

The average weight-to-length ratio in the macrosomic rats in the Mature+Diet Group was almost the same as those in the Control Group.

At the age of 6 months, descendants of the rats in all macrosomic groups had the average body weight, the average body length, and the average weight-to-length ratio comparable to those in the Control Group (see Table 1). However, the average body weight in the Hypokinetic+Diet Group was reliably lower than in the Physical Development Acceleration Group.

When analyzing the details of the minor salivary gland at tissue level (see Table 2), the more pronounced stroma and less pronounced parenchyma, in comparison with Control Group, are observed in Young +diet, Physical Development Acceleration Groups. Hence, the gland parenchyma in animals may be said to be hypoplastic in all macrosomic groups, except Hypokinetic+diet Group, including the Mature+Diet Group (macrosomic descendants of mature female rats who were fed on a hyper-caloric diet), since these animal acini have relatively large gap area cross-section.

Obviously, the area of the acinus cross-section depends on the number of acinar cells and on the size of each of them, which reflects the degree morphofunctional load on the salivary gland.

The study of the average morphometric indices of separate acini reveals a decrease in the total area of mucous acinar cells cross-section in animals in all macrosomic groups (see Table 3), and the acinar area cross-section reliably decreases only in the macrosomic descendants of young parents who were fed on a hypercaloric diet during pregnancy (Young +Diet Group).

A decrease in the area of mucous acinar cells crosssection in minor buccal salivary glands in different macrosomic groups occur via the following different mechanisms: both smaller and lower mucous acinar cells in the Young+Diet Group (see Figure 4, left pannel); the size of acini in the animals in the Mature+Diet Group is comparable to that in the Control Group, but the cytoplasm height is the smallest among all animals under study; the size of acini in the animals in the Physical Development Acceleration Group is also comparable to that in the Control Group, but the cytoplasm height is smaller than that in the Control Group; a small decrease in the acinus size is accompanied by a small decrease in the cytoplasm height that result in a decrease in the total area occupied by mucous acinar cells in acinus in the Hypokinetic+Diet Group. In the latter group, a reliable decrease in the number of mucous acinar cells in minor salivary gland acinus is exactly observed (Table 3), i.e., the salivary gland hypoplasticity exists at the tissue level in all the macrosomic descendants of young parents who were fed on a hyper-caloric diet during pregnancy that was passing under conditions of mild hypokinesia. A decrease in the cytoplasm height of musous acinar cells in acinus is a marker for a decrease in the secretory acinar cells morphofunctunal activity.

Furthermore, the acini outer boundary is found to be rough (crimp) in minor salivary glands in the animals in the Hypokinetic+Diet and Young+Diet Groups, which most probably arise as a result of an increase in the necessity of producing saliva that causes functional overloading, and consequently the acini boundary shrinks and becomes rough (see Figure 5, right pannel).

Thus, the morphometric study of minor buccal salivary glands samples by confocal microscopy have shown that the expectation value of the average area of the minor buccal salivary gland acini cross-section in the Mature+Diet Group and Physical Development Acceleration Group is comparable to that in the Control Group, whereas in the Hypokinetic+Diet Group, it is established to be reduced and in the Young+Diet Group is reliably reduced.

The mean value of the average area of minor salivary gland acini gap is sharply increased in the animals in the Mature+Diet Group (see Figure 4, right pannel) and Physical Development Acceleration Group (see Figure 5 , left pannel), which is most likely due to the features inherent in the morphofunctional cycle of mucous acinar cells, i.e., due to a decrease in their cytoplasm height.

The mean value of the area of the parenchymal tissue in the minor salivary gland acini is, in our opinion, a more informative indicator, which turns out to be of a lesser amount in animals in all macrosomic groups as compared to the Control Group (Table 3). Moreover, in the animals Young+Diet Group, a decrease is reliably established within $95 \%$ confidence interval.

\section{DISCUSSION}

According to the literature [24], the minor salivary glands produce only a small part of the saliva, about $10 \%$ 
of the total volume, but their microscopic features repeat those of the major salivary glands, and $70 \%$ of the total volume of proteins, which are produced by the salivary glands, are produced by the minor salivary glands.

The formation and acinar differentiation of the mixed secretion salivary glands occur mainly prenatally [25, 26], and the intra-uterine forming epigenetic changes in metabolism and the morphofunctional state of the glands can persist for life and affect the cariogenic situation in oral cavity.

The results obtained have an indirect confirmation: when evaluating the condition of hard tooth tissues in experimental animals, it is noteworthy, that at the age of 6 months, the number of teeth affected by caries in animals born with macrosomia is increased in comparison with the Control Group.

In summary, our study demonstrated that the morphometric parameters of the minor buccal salivary glands in the experimental animals that were born with macrosomia differ significantly from the parameters of the minor buccal salivary glands in animals with normal weight-growth parameters at birth. These differences are most pronounced in animals in the Young+Diet Group and the Hypokinetic+Diet Group (which have the signs of intrauterine obesity at birth) compared to those in the group of intact animals.

The nonparametric tests have shown differences between such acinus parameters as the area of mucous acinar cells cross-section in minor salivary gland acini and the average perimeter of minor salivary gland acini in animals in Young+Diet and Control Groups at significance levels, $\mathrm{p}$, less than 0.05 . The parameters under study in young animals are smaller than in the animals in Control Group.

In rats born with various fetal macrosomia modeling, on reaching the age of 6 months, the deviations from the parameters in the Control Group were revealed in the following: the acinus area, the acinus gap area, the number of serous acinar cells in the acinus, the height of the mucous acinar cells, and the relative stroma of the gland. The assessment of these deviations allows us to speak about the presence of hypoplasia in the minor buccal salivary glands.

Data listed above should be taken into consideration in human patients diagnosed with fetal macrosomia. A better understanding of violation in minor buccal salivary glands morphogenesis may be a key to explaining the dental disorder formation and the basis for creating new approaches to predicting, effective methods of prevention, and rational treatment of diseases of hard tooth tissues, inflammatory-dystrophic diseases of periodontal tissues and other dental violations in the patients we care for.

\section{CONFLICT OF INTEREST}

Olga Garmash: the concept of the study, pattern analysis, manuscript preparation

Vondrášek David: microscope setup and image acquisition

Galina Gubina-Vakulik: pattern analysis

\section{ACKNOWLEDGMENET}

This work was supported by the BioImaging Facility, Institute of Physiology, supported by the CzechBioImaging large RI project (LM2015062 funded by MEYS CR) and by the project Modernization and support of research activities of the national infrastructure for biological and medical imaging Czech-BioImaging (CZ.02.1.01/0.0/0.0/16_013/0001775 funded by OP $\mathrm{RDE})$.

The authors wish to thank Dr. Lucie Kubínová and Dr. Jiří Janáček for their helpful advice in various technical issues and Mgr. Daniel Hadraba for his advice and comments.

\section{REFERENCES}

1. Lahmann PH, Wills RA, Coory M. Trends in birth size and macrosomia in Queensland, Australia, from 1988 to 2005. Paediatr Perinat Epidemiol 2009; 23:533-41.

2. Koyanagi A, Zhang J, Dagvadorj A, et al. Macrosomia in 23 developing countries: an analysis of a multicountry, facility-based, cross-sectional survey. Lancet 2013; 381:476-83.

3. Zhang X, Decker A, Platt RW, Kramer MS. How big is too big? The perinatal consequences of fetal macrosomia. Am J Obstet Gynecol 2008; 198:517.e1-6.

4. Godfrey KM, Barker DJ. Fetal nutrition and adult disease. Am J Clin Nutr 2000; 71(5): 1344-52.

5. Gu S, An X, Fang L, et al. Risk factors and long-term health consequences of macrosomia: a prospective study in Jiangsu Province, China. J Biomed Res 2012; 26:235-40.

6. Samaras TT, Elrick H, Storms LH. Birthweight, rapid growth, cancer, and longevity: a review. J Natl Med Assoc 2003; 95:1170-83.

7. Hermann GM, Dallas LM, Haskell SE, Roghair RD. Neonatal macrosomia is an independent risk factor for adult metabolic syndrome. Neonatology 2010; 98: 238-44.

8. Huraseva AB. Substantiation of the differentiated approach to a dispensary observation of the girls who have been born with different birth weight. J of Obst and Women's Diseases 2007; 3: 37-43 (in Russian). 
9. Yokomichi H, Tanaka T, Suzuki K, Akiyama T, Okinawa Child Health Study Group, Yamagata Z. Macrosomic neonates carry increased risk of dental caries in early childhood: findings from a cohort study, the Okinawa child health study, Japan. PLoS One, 2015; 10:e0133872.

10. Julihn A, Molund U, Drevsäter E, Modéer T. High birth weight is a risk factor of dental caries increment during adolescence in Sweden. Dent J 2014; 2: 118-33.

11. Redman RS. Morphologic diversity of the minor salivary glands of the rats: fertile ground for studies in gene function and proteomics. Biotech Histochem 87:273-87.

12. Cunha-Cruz J, Scott J, Rothen M, [et al.]. Salivary characteristics and dental caries: evidence from general dental practices. J Am Dent Assoc 2013; 144:e31-40.

13. Shetty CM, Hegde MN, Devadiga D. Correlation between dental caries with salivary flow, ph, and buffering capacity in adult south Indian population: An in-vivo study. International Journal of Research in Ayurveda and Pharmacy 2013; 4:219-23.

14. Hodgson TA, Shah R, Porter SR. The investigation of major salivary gland agenesis: a case report. Pediatr Dent 2001; 23:131-4.

15. Fracaro MS, Linnett VM, Hallett KB, Savage NW. Submandibular gland aplasia and progressive dental caries: a case report. Australian Dental Journal 2002; 47:347-50.

16. Tandon A, Singh NN, Sreedhar GJ. Minor salivary glands and dental caries: approach towards a new horizon. J Nat Sci Biol Med 2013; 4:364-8.

17. Kubínová L, Janáček J. Confocal stereology: an efficient tool for measurement of microscopic structures. Cell Tissue Res 2015; 360:13-28.
18. Kubínová L, Mao XW, Janáček J. Blood capillary length estimation from three-dimensional microscopic data by image analysis and stereology. Micros Microanal 2013; 19:898-906.

19. Janáček J, Čapek M, Michálek J, Karen P, Kubínová L. 3D microscopic imaging and evaluation of tubular tissue architecture. Physiol Res 2014; 63:S49-55.

20. Eržen I, Janáček J, Kubínová L. Characterization of the capillary network in skeletal muscles from 3D data. Physiol Res 2011; 60:1-13.

21. Hermann GM, Dallas LM, Haskell SE, Roghair RD. Neonatal macrosomia is an independent risk factor for adult metabolic syndrome. Neonatology 2010; 98: 238-44.

22. Gubina-Vakulyk, G. (1994). Patologichna anatomiia endokrynnyh zaloz plodu pry adaptatsii vagitnoi do dii okremyh seredovyshchnyh faktoriv [Pathological anatomy of the fetal endocrine glands in pregnant woman adaptation to the some environmental factors action]. Doktor medychnyh nauk: 14.00.15. Kharkiv National Medical University. [In Ukrainian].

23. Schindelin J, Arganda-Carreras I, Frise E, et al. Fiji: an open-source platform for biological-image analysis. Nat Methods 2012; 9:676-82.

24. Xuedong Z. Dental Caries: Principles and Management Eds. 1th ed. Springer-Verlag Berlin Heidelberg. 2016.

25. Wolff MS, Mirels L, Lagner J, Hand AR. Development of the rat sublingual gland: a light and electron microscopic immunocytochemical study. Anat Rec 2002; 266:30-42.

26. Redman RS. On approaches to the functional restoration of salivary glands damaged by radiation therapy for head and neck cancer, with a review of related aspects of salivary gland morphology and development. Biotech Histochem 2008; 83:103-30. 